\title{
Constatação do Banana streak Uganda B virus em bananeiras no Estado do Pará
}

\author{
Luiz Sebastião Poltronieri ${ }^{1}$, Daniel Vazquez Figueiredo², Paulo Sergio Torres Brioso², Jaqueline Rosemeire \\ Verzignassi $^{3}$, Shirley Sousa Cardoso ${ }^{4}$
}

\begin{abstract}
${ }^{1}$ Embrapa Amazônia Oriental, Trav. Dr. Enéas Pinheiro, s/nº, CEP 66.095-100, Belém,PA; e-mail: poltroni@cpatu.embrapa.br. ${ }^{2}$ Laboratório Oficial de Diagnóstico Fitossanitário/Área de Fitopatologia/DEF/IB/UFRRJ, Caixa Postal 74585, CEP 23851-970, Seropédica, RJ; ${ }^{3}$ Embrapa Gado de Corte, Rod. BR 262, Km 4, Caixa Postal 154, CEP 79002-970, Campo Grande, MS. ${ }^{4}$ Secretaria de Desenvolvimento, Ciência e Tecnologia, Av. Presidente Vargas, 1.020. Centro. CEP 66017-000. Belém. Pará.
\end{abstract}

Autor para correspondência: Luiz Sebastião Poltronieri

Data de chegada: 14022007. Aceito para publicação em: 11/08/2008

O Estado do Pará destacou-se, de 1998 a 2000, como o maior produtor de bananas do País. Em 2005, tornou-se o terceiro colocado, com praticamente a mesma produção do Estado da Bahia, o segundo produtor nacional. A maior parte da produção de bananas no Pará é de áreas de agricultores familiares, com baixo nível tecnológico, e se concentra na mesorregião sudeste paraense. A ocorrência de doenças, porém, tem contribuído para a baixa produtividade dos bananais no Pará, destacando-se a sigatoka-negra, sigatoka-amarela, mal-do-Panamá e moko. Em três propriedades rurais, situadas no Município de São Domingos do Araguaia, foram coletadas amostras de folhas de plantas da cultivar Mysore e Inajá, com sintomas iniciais de estrias cloróticas que evoluíam para necróticas (Fig. 1), culminando com o secamento das folhas.

Das amostras, procedeu-se a extração dos ácidos nucléicos totais e, para a purificação do DNA, utilizou-se o produto DNAzol (Invitrogen), utilizando-se a metodologia recomendada pelo fabricante. Como controle positivo foi utilizada amostra de folhas da cultivar Prata Anã (AAB) infectada com Banana streak Uganda B virus (BSUgBV).

Após a extração e purificação do DNA, procedeu-se análise por PCR (Polymerase Chain Reaction). Para tanto, a um tubo de polipropileno de $0,2 \mathrm{~mL}$ foram adicionados $5 \mu \mathrm{L}$ de tampão 10X PCR da enzima Taq polimerase (Amersham), $1 \mathrm{~mL}$ da mistura de dNTP (2,5 mM cada), 50 pmoles dos oligonucleotídeos BADNA 2 e MYS 3', 1,25 U da enzima Taq polimerase (Amersham), $2 \mu \mathrm{L}$ de DNA total e água destilada estéril, para $50 \mu \mathrm{L}$ de volume final. Os tubos, contendo o material da reação, foram colocados no termociclador programável PTC-200 (MJ RESEARCH) e submetidos a um ciclo inicial de $94^{\circ} \mathrm{C} /$ 5 minutos, $42^{\circ} \mathrm{C} / 2$ minutos e $72^{\circ} \mathrm{C} / 3$ minutos; 25 ciclos de $94^{\circ} \mathrm{C} / 1$ minuto, $42^{\circ} \mathrm{C} / 2$ minutos e $72^{\circ} \mathrm{C} / 3$ minutos e a um ciclo final de $94^{\circ} \mathrm{C} /$ 1 minuto, $42^{\circ} \mathrm{C} / 2$ minutos e $72^{\circ} \mathrm{C} / 10$ minutos.

Os produtos amplificados foram aplicados em gel de agarose (1\%), contendo brometo de etídio $(5 \mu \mathrm{g} / \mathrm{mL})$, submetidos à eletroforese e visualizados em transiluminador de luz ultravioleta.

As três amostras analisadas foram positivas para Banana streak Uganda B virus (BSUgBV) e este resultado reforça dados anteriores que relatam a ampla distribuição de badnavirus em bananeiras no território nacional.

Foi demonstrada, por meio de PCR, a ocorrência de quatro isolados do BSV no Brasil, que apresentavam seqüências com perfis

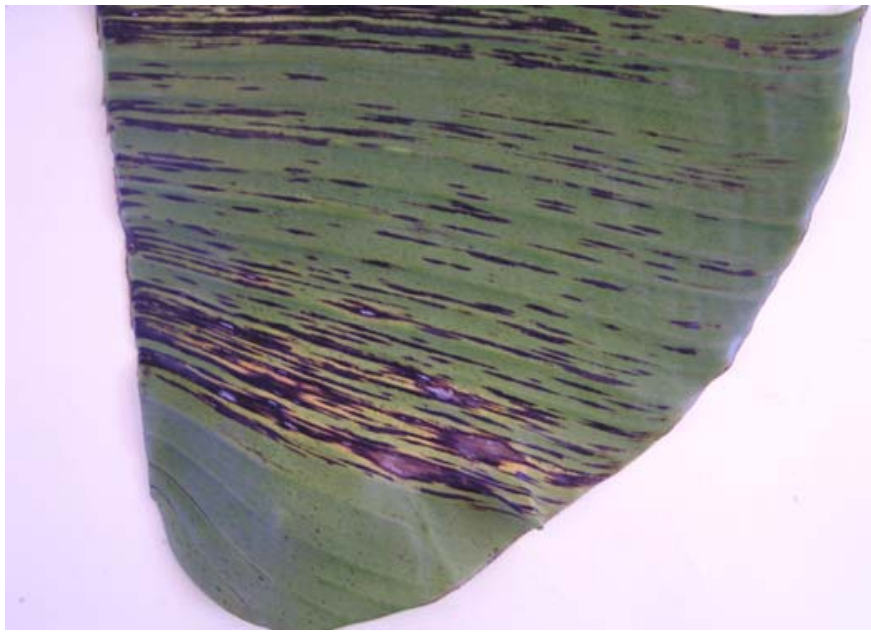

Figura 1. Estrias necróticas em folha de bananeira cv. Mysore causadas por Banana streak Uganda B virus (BSUgBV).

eletroforéticos distintos, então classificados como BSVBR-1, BVBR2, BSVBR-3 e BSVBR-4. Posteriormente, foi verificado que estes isolados representavam diferentes espécies. O isolado BSVBR-1 pertence à espécie BSUgBV, enquanto os isolados BSVBR-2, BSVBR3 e BSVBR-4 representam possíveis novas espécies, então denominadas Banana streak Brazil 1 virus (BSBr1V), Banana streak Brazil 2 virus (BSBr2V) e Banana streak Brazil 3 virus (BSBr3V), respectivamente.

O perfil eletroforético dos produtos amplificados indicaram que, nas amostras coletadas, havia a presença do BSUgBV. Este trabalho representa o primeiro relato da presença desta espécie de Badnavirus no Estado do Pará.

Alguns trabalhos apontam a grande variabilidade genômica existente entre os Badnavirus. Desta forma, a presença somente do BSUgBV nas amostras analisadas sugere que as cultivares de bananeiras analisadas podem ter a mesma origem.

A metodologia empregada neste trabalho é bastante útil para diagnosticar a presença de Badnavirus em bananeira, podendo ser aplicada em material propagativo com vistas à reduzir a disseminação do patógeno para área isentas. 